\title{
ANCAMAN GELOMBANG EKSTRIM DAN ABRASI PADA PENGGUNAAN LAHAN DI PESISIR KEPULAUAN KARIMUNJAWA (STUDI KASUS: PULAU KEMUJAN, PULAU KARIMUNJAWA, PULAU MENJANGAN BESAR DAN PULAU MENJANGAN KECIL)
}

\author{
THE EXTREME WAVES AND ABRASION HAZARDS ON COASTAL LAND USE AT \\ KARIMUNJAWA ISLANDS (CASE STUDY: KEMUJAN ISLAND, KARIMUNJAWA ISLAND, \\ MENJANGAN BESAR ISLAND AND MENJANGAN KECIL ISLAND)
}

\author{
Dini Purbani, Hadiwijaya Lesmana Salim, Luh Putu Ayu Savitri Chitra Kusuma, \\ Armyanda Tussadiah \& Joko Subandriyo \\ Pusat Riset Kelautan, Badan Riset dan Sumberdaya Kelautan dan Perikanan, \\ Kementerian Kelautan dan Perikanan \\ Jl. Pasir Putih I, Ancol Timur, Jakarta Utara 14430 \\ e-mail : dinipurbani@gmail.com
}

Diterima tanggal: 22 Oktober 2018 ; diterima setelah perbaikan: 2 April 2019 ; Disetujui tanggal: 20 April 2019 DOI: http://dx.doi.org/10.15578/jkn.v14i1.7207

\begin{abstract}
ABSTRAK
Kepulauan Karimunjawa yang terletak di lepas pantai Kabupaten Jepara, Provinsi Jawa Tengah, merupakan gugus pulau-pulau kecil yang terdiri dari 27 pulau. Sebagian kawasan Kepulauan Karimunjawa seluas 1.116,25 $\mathrm{km}^{2}$ telah ditetapkan sebagai Taman Nasional Karimunjawa. Secara geografis wilayah kepulauan Indonesia, termasuk Kepulauan Karimunjawa, berada pada kawasan rawan bencana, dengan potensi tinggi terjadinya berbagai bencana hidrometeorologi, seperti gelombang ekstrim dan abrasi. Kepulauan Karimunjawa rawan bencana terutama karena kondisi alam dan geografi setempat. Gelombang ekstrim dapat mengakibatkan terjadinya gelombang pasang dan abrasi di Kepulauan Karimunjawa. Mengukur tingkat ancaman gelombang ekstrim dan abrasi di pesisir pantai merupakan bagian dari suatu kajian risiko bencana di daerah rawan bencana. Penelitian ini dilakukan di Kepulauan Karimunjawa menggunakan metode penghitungan indeks ancaman gelombang ekstrim dan abrasi berdasarkan Peraturan Kepala Badan Nasional Penangulangan Bencana No. 2/2012 tentang Pedoman Umum Pengkajian Risiko Bencana, dengan parameter tinggi gelombang, arus, tutupan vegetasi, bentuk garis pantai dan tipologi pantai, difokuskan di daerah sempadan pantai. Proses analisis data menggunakan perangkat lunak keruangan ArcGIS dan ER Mapper. Hasil analisis menunjukkan terdapat tiga kelas ancaman gelombang ekstrim dan abrasi di daerah sempadan pantai di lokasi studi, yaitu rendah $(0,01 \%)$, sedang (19,33\%) dan tinggi (80,67\%). Penggunaan lahan yang terkena ancaman gelombang ekstrim dan abrasi yaitu perkebunan $(48,33 \%)$, hutan mangrove $(23,28 \%)$ dan vegetasi $(13,05 \%)$.
\end{abstract}

Kata kunci: Gelombang ekstrim, abrasi, Kepulauan Karimunjawa, risiko bencana, sempadan pantai.

\section{ABSTRACT}

Karimunjawa Islands, located off the coast of Jepara Regency, Central Java Province, is a small island group consisting of 27 islands. Some areas of Karimunjawa Islands covering 1,116.25 km have been designated as Karimunjawa National Park. Geographically the Indonesian Archipelago, including the Karimunjawa Islands, is located in disaster vulnerable areas, with high potential for various hydrometeorological disasters, such as extreme waves and abrasion. Karimunjawa Islands is vulnerable to disasters mainly due to its natural conditions and local geography. Extreme waves can lead to tidal waves and marine erosion in the Karimunjawa Islands. Measuring the level of extreme waves and abrasion hazards in the coastal areas is part of a disaster risk assessment in disaster vulnerable areas. This study was conducted in Karimunjawa Islands using the method of calculating extreme waves and abrasion hazards index based on the Regulation of the Head of National Agency for Disaster Management No. 2/2012 on General Guidelinefor Disaster Risk Assessment, with parameters of wave height, current, vegetation cover, shoreline shape and coastal typology, focusedin coastal setback areas. Data analysis processes were using ArcGIS and ER Mapper spatial software. The analysis shows that there were three classes of extreme waves and abrasion hazards in the the study area,i.e.low (0.01\%), moderate (19.33\%) and high (80.67\%). The land uses exposed to the extreme waves and abrasion hazards were plantations (48.33\%),

Ancaman Gelombang Ekstrim dan Abrasi pada Penggunaan Lahan di Pesisir Kepulauan Karimunjawa (Studi Kasus:

Pulau Kemujan, Pulau Karimunjawa, Pulau Menjangan Besar dan Pulau Menjangan Kecil) - Dini Purbani, Hadiwijaya

Lesmana Salim, Luh Putu Ayu Savitri Chitra Kusuma, Armyanda Tussadiah \& Joko Subandriyo 


\section{PENDAHULUAN}

Kepulauan Karimunjawa secara geografis terletak di antara $5^{\circ} 40^{\prime}-5^{\circ} 57^{\prime} \mathrm{LS}$ dan $110^{\circ} 04^{\prime}-110^{\circ} 40^{\prime} \mathrm{BT}$ dengan jarak sekitar 60 mil laut di sebelah timur laut Kota Semarang. Kepulauan Karimunjawa dengan wilayah daratan seluas $71,2 \mathrm{~km}^{2}$, secara administratif merupakan salah satu kecamatan di wilayah Kabupaten Jepara, Provinsi Jawa Tengah, dan terdiri dari empat desa yaitu Desa Karimunjawa, Desa Kemujan, Desa Parang, dan Desa Nyamuk. Sesuai definisi pulau kecil menurut UU No. 27 Tahun 2007 beserta perubahannya (UU No. 1 Tahun 2014) tentang Pengelolaan Wilayah Pesisir dan Pulau-Pulau Kecil, yaitu pulau dengan luas lebih kecil atau sama dengan $2.000 \mathrm{~km}^{2}$ beserta kesatuan ekosistemnya, Kepulauan Karimunjawa merupakan gugus pulau-pulau kecil. Kepulauan Karimunjawa terdiri dari 27 pulau, dimana 22 pulau diantaranya termasuk ke dalam kawasan Taman Nasional Karimunjawa. Permukiman penduduk hanya terdapat di lima pulau terbesar, yaitu Pulau Karimunjawa $\left(43,025 \mathrm{~km}^{2}\right)$, Pulau Kemujan $(15,015$ $\left.\mathrm{km}^{2}\right)$, Pulau Parang $\left(6,92 \mathrm{~km}^{2}\right)$, Pulau Genting $(1,37$ $\mathrm{km}^{2}$ ) dan Pulau Nyamuk $\left(1,26 \mathrm{~km}^{2}\right)$. Pulau-pulau lain tidak berpenduduk, diantaranya Pulau Bengkoang $\left(0,79 \mathrm{~km}^{2}\right)$, Pulau Menjangan Besar $\left(0,56 \mathrm{~km}^{2}\right)$, dan Pulau Menjangan Kecil $\left(0,46 \mathrm{~km}^{2}\right)$. Jumlah penduduk di Kepulauan Karimunjawa pada tahun 2016 adalah sebanyak 9.379 jiwa (BTNK, 2004; Suryanti, 2010; BPS Kab. Jepara, 2017). Kepulauan Karimunjawa semula ditetapkan sebagai cagar alam laut berdasarkan SK Menteri Kehutanan No. 123/Kpts-II/1986 tanggal 9 April 1986 tentang Penunjukan Kepulauan Karimunjawa dan Perairan Laut di Sekitarnya seluas 111.625 ha yang terletak di Dati II Jepara Jawa Tengah sebagai Cagar Alam Laut. Selanjutnya berdasarkan SK Menteri Kehutanan dan Perkebunan No. 78/KptsII/1999 tanggal 22 Februari 1999, kawasan Cagar Alam Karimunjawa dan perairan disekitarnya seluas 111.625 ha yang terletak di Kabupaten Dati II Jepara Propinsi Dati I Jawa Tengah ditetapkan menjadi taman nasional dengan nama Taman Nasional Karimunjawa. Pada tahun 2001 seluruh kawasan perairan di Taman Nasional Karimunjawa ditetapkan sebagai kawasan pelestarian perairan melalui SK Menteri Kehutanan No. 74/Kpts-II/2001 tanggal 15 Maret 2001. Kawasan
Taman Nasional Karimunjawa dengan total luasan $1.116,25 \mathrm{~km}^{2}$ (111.625 ha), terdiri dari hutan hujan tropika dataran rendah seluas $12,855 \mathrm{~km}^{2}$, hutan mangrove seluas $2,222 \mathrm{~km}^{2}$ dan sisanya perairan seluas $1.101,173 \mathrm{~km}^{2}$ (BTNK, 2004; Suryanti, 2010).

Geologi Pulau Kemujan berada dalam formasi parang yang tersusun oleh breksi gunung api tuff dan lava sebagai hasil produk vulkanik, dan di beberapa tepi pantai sudah ada yang teralterasi. Pulau Karimunjawa berada di formasi Karimunjawa dengan litologi batuan batupasir kuarsa, mikaan, konglomerat kuarsa, batu lanau kuarsa dan serpih kuarsa. Pulau Menjangan Besar dan Pulau Menjangan Kecil memiliki litologi berupa kerakal, kerikil, pasir, lempung, lumpur, pecahan koral dan batuapung (Sidarto \& Hermanto, 1993) . Formasi litologi batuan di pulau-pulau ini mempengaruhi tipologi pantai. Pulau Karimunjawa termasuk jenis pulau petabah (Hehanusa, 1993; Hadi et al., 2006). Pulau Petabah terbentuk di daerah yang stabil secara tektonik, dengan litologi pembentukan terdiri atas batuan ubahan (metamorf), intrusi dan sedimen yang terlipat dan berumur tua (Bengen et al., 2012). Di satu sisi perairan laut Kepulauan Karimunjawa tergolong sebagai perairan dangkal, sehingga pengaruh angin yang relatif kecil saja sudah dapat menimbulkan gelombang di permukaan laut. Dalam periode angin barat laut, wilayah perairan di Kepulauan Karimunjawa sering mengalami gelombang yang cukup besar berkisar antara 0,56-1,58 m (BTNK, 2004; Suryanti, 2010) dengan kecepatan arus permukaan berkisar antara 8-25 cm/detik. Seperti dilaporkan oleh Stasiun Meteorologi Maritim (Stamar) Kelas II Semarang (Karimun Jawa, 2016), pada tanggal 29 Juni 2016 di perairan Laut Jawa dengan kecepatan angin $2-20 \mathrm{~km} /$ jam, ketinggian gelombang bergerak naik bervariasi, dimana tinggi gelombang di perairan Karimunjawa 0,3-1 m. Musa et al. (2013) menyatakan bahwa tipe pasang surut di perairan Pulau Karimunjawa adalah campuran condong ke harian tunggal, begitu juga dengan pulau-pulau kecil di sekitarnya (Fachrurrozi et al., 2013) dimana dalam satu hari terjadi satu kali pasang naik dan satu kali pasang turun tetapi terkadang untuk sementara waktu dapat terjadi dua kali pasang naik dan dua kali pasang turun dengan tinggi dan periode yang berbeda. 
Ancaman bencana menurut UU No. 24 Tahun 2007 tentang Penanggulangan Bencana adalah suatu kejadian atau peristiwa yang bisa menimbulkan bencana. Adapun rawan bencana adalah kondisi atau karakteristik geologis, biologis, hidrologis, klimatologis, geografis, sosial, budaya, politik, ekonomi, dan teknologi pada suatu wilayah untuk jangka waktu tertentu yang mengurangi kemampuan mencegah, meredam, mencapai kesiapan, dan mengurangi kemampuan untuk menanggapi dampak buruk bahaya tertentu (UU 24/2007). Perlu dilakukan mitigasi bencana sesuai dengan dalam UU No 26 Tahun 2007 dalam UU No 26 Tahun 2007 tentang Penataan Ruang, secara geografis wilayah NKRI berada pada kawasan rawan bencana. Posisi Indonesia yang terletak di garis katulistiwa dan berbentuk kepulauan menimbulkan potensi tinggi terjadinya berbagai jenis bencana hidrometeorologi, seperti banjir, kekeringan, cuaca ekstrim (angin puting beliung), gelombang ekstrim dan abrasi, serta kebakaran hutan dan lahan (BNPB, 2014). Kepulauan Karimunjawa rawan akan bencana terutama karena kondisi alam dan geografi setempat. Karimunjawa terletak di Laut Jawa yang merupakan perairan dalam sehingga mengakibatkan sering diterjang oleh gelombang pasang (Ruswandi et al., 2008). Dampak dari gelombang yang cukup besar dapat mengakibatkan terjadi erosi pantai, gelombang pasang, intrusi air laut serta banjir dan rob di Kepulauan Karimunjawa (BTNK, 2004; Suryanti, 2010).

Risiko bencana adalah potensi kerugian yang ditimbulkan akibat bencana pada suatu wilayah dan kurun waktu tertentu yang dapat berupa kematian, luka, sakit, jiwa terancam, hilangnya rasa aman, mengungsi, kerusakan atau kehilangan harta, dan gangguan kegiatan masyarakat (UU 24/2007). Memperhatikan adanya risiko bencana di suatu wilayah, maka perlu dilakukan pengkajian risiko bencana, yaitu sebuah pendekatan untuk memperlihatkan potensi dampak negatif yang mungkin timbul akibat suatu potensi bencana yang ada, yang menjadi landasan penyelenggaraan penanggulangan bencana untuk mengurangi risiko bencana. Pengkajian risiko bencana disusun berdasarkan komponen pembentuk risiko bencana, yaitu ancaman, kerentanan dan kapasitas (BNPB, 2012; Amri et al., 2016). Indonesia secara umum memiliki 13 jenis ancaman bencana; salah satunya adalah ancaman gelombang ekstrim dan abrasi (BNPB, 2012). Menurut Peraturan Kepala Badan Meteorologi, Klimatologi, dan Geofisika No. KEP. 009 Tahun 2010, gelombang laut ekstrim adalah gelombang laut signifikan dengan ketinggian $\geq 2 \mathrm{~m}$. Sedangkan abrasi adalah proses dimana terjadi pengikisan pantai yang disebabkan oleh tenaga gelombang laut dan arus laut yang bersifat merusak, dan kerusakan garis pantai dikarenakan terganggunya keseimbangan alam di daerah pantai tersebut (Amri et al., 2016). Berdasarkan hasil kajian risiko bencana, jumlah penduduk terpapar risiko bencana gelombang ekstrim dan abrasi di Indonesia adalah sebanyak 9.825.782 jiwa di seluruh provinsi dengan potensi kerugian mencapai $\mathrm{Rp} 259$ trilyun (BNPB, 2014).

Penelitian ini dilakukan untuk membuat peta ancaman gelombang ekstrim dan abrasi di Kepulauan Karimunjawa berdasarkan metode yang termuat di dalam Peraturan Kepala (Perka) BNPB No. 2 Tahun 2012 tentang Pedoman Umum Pengkajian Risiko Bencana (BNPB, 2012). Metode ini dipilih karena sesuai dengan kondisi geografis Kepulauan Karimunjawa, dimana memungkinkan terjadi bencana yang disebabkan oleh faktor alam yang mengancam dan mengganggu kehidupan dan penghidupan masyarakat. Berdasarkan Rencana Nasional Penanggulangan Bencana 2015-2019 (BNPB, 2014), Provinsi Jawa Tengah termasuk salah satu lokasi prioritas nasional guna dilakukan fokus kegiatan penanggulangan bencana abrasi. Bencana gelombang ekstrim kerap terjadi di Kepulauan Karimunjawa terutama di sisi barat dan timur yang menyebabkan erosi, sehingga pemerintah daerah setempat membangun tembok laut (seawall) untuk menahan gelombang (BTNK, 2004; Suryanti, 2010). Ancaman bencana gelombang ekstrim dan abrasi yang terjadi di pesisir dalam penelitian ini difokuskan di daerah sempadan pantai, yaitu daratan sepanjang tepian pantai yang lebarnya proporsional dengan bentuk dan kondisi fisik pantai, minimal $100 \mathrm{~m}$ dari titik pasang tertinggi ke arah darat (UU 27/2007 jo. UU 1/2014) dan merupakan kawasan perlindungan setempat (UU 26/2007). Sempadan pantai berfungsi untuk melindungi dan menjaga kelestarian fungsi ekosistem dan sumberdaya di wilayah pesisir dan pulau-pulau kecil dan kehidupan masyarakatnya dari ancaman bencana alam (Perpres 51/2016). Penelitian ini menggunakan pendekatan analisis dengan aplikasi penginderaan jauh dan Sistem Informasi Geografis (SIG) untuk mendapatkan tingkat dan luas sebaran ancaman gelombang ekstrim dan abrasi. Penginderaan jauh diperlukan untuk mendapatkan informasi penggunaan lahan yang terkini dengan cara melakukan ekstraksi dari data citra. Sistem penginderaan jauh dan teknik analisis citra telah dikembangkan untuk memperluas pengamatan aktivitas di bumi dalam mendukung pengelolaan bencana alam yang terjadi sebagai bentuk 
situasi kritis kemanusian. Standarisasi data dari fasilitas industri dan infrastruktur yang vital bersinergi dengan lingkungan untuk dapat mengetahui bencana yang terjadi sehingga perlu ditingkatkan persiapan dalam pengelolaan mitigasi. Beberapa penggunaan lahan dan hutan merupakan unsur yang dinamis di alam sehingga perlu dilakukan pembaharuan data secara berkala (Theilen-Willige et al., 2012). Oleh karena itu perlu dilakukan persiapan menghadapi bencana menggunakan data permukiman, infrastruktur, fasilitas industri dan yang lainnya secara akurat agar proses mitigasi dapat segera dilakukan. SIG merupakan teknologi informasi untuk membuat database dengan informasi keruangan yang dapat diaplikasikan baik untuk permukiman (misalnya database demografik) dan lingkungan alam (misalnya sebaran populasi dan faktor-faktor lingkungan). Pengintegrasian dengan SIG ini dapat membantu untuk mengkaji lebih baik terhadap risiko dan mitigasinya (Garcin et al., 2008). Kombinasi dari kedua jenis database ini dapat menjamin pembangunan berkelanjutan. SIG merupakan alat akuisisi dan analisis data yang diperlukan dalam analisis deskriptif keruangan serta dalam perencanaan lingkungan, analisis dampak, pengelolaan bencana dan pemantuan penginderaan jauh (Dahdouh-guebas, 2002).

\section{BAHAN DAN METODE}

\section{Tujuan Penelitian}

Penelitian ini bertujuan untuk mengetahui lokasi dan penggunaan lahan di pesisir yang rawan akan ancaman gelombang ekstrim dan abrasi di Pulau Kemujan, Pulau Karimunjawa, Pulau Menjangan Besar dan Pulau Menjangan Kecil di wilayah Kepulauan Karimunjawa. Dengan diketahuinya lokasi yang rawan bencana maka perlu diketahui tingkat dan luas sebaran ancaman gelombang ekstrim dan abrasi di pesisir Pulau Kemujan, Pulau Karimunjawa, Pulau Menjangan Besar dan Pulau Menjangan Kecil. Dengan demikian penduduk, pengunjung dan para pemangku kepentingan (stakeholders) lainnya di Kepulauan Karimunjawa, dapat menyedari keberadaannya di lokasi rawan bencana, khususnya gelombang ekstrim dan abrasi.

\section{Lokasi dan Waktu Penelitian}

Penelitian ini dilaksanakan di wilayah Kepulauan Karimunjawa, Kabupaten Jepara, Provinsi Jawa Tengah, dengan lokasi difokuskan di Pulau Kemujan, Pulau Karimunjawa, Pulau Menjangan Besar dan Pulau Menjangan Kecil. Pengambilan data lapangan dilakukan pada pertengahan bulan Mei sampai dengan awal Juni 2016, kemudian dilanjutkan pengolahan dan analisis data pada tahun 2017 hingga Maret 2018. Lokasi penelitian ditunjukan pada Gambar 1.

\section{Pembuatan Peta Ancaman Gelombang Ekstrim dan Abrasi}

Peta ancaman gelombang ekstrim dan abrasi merupakan

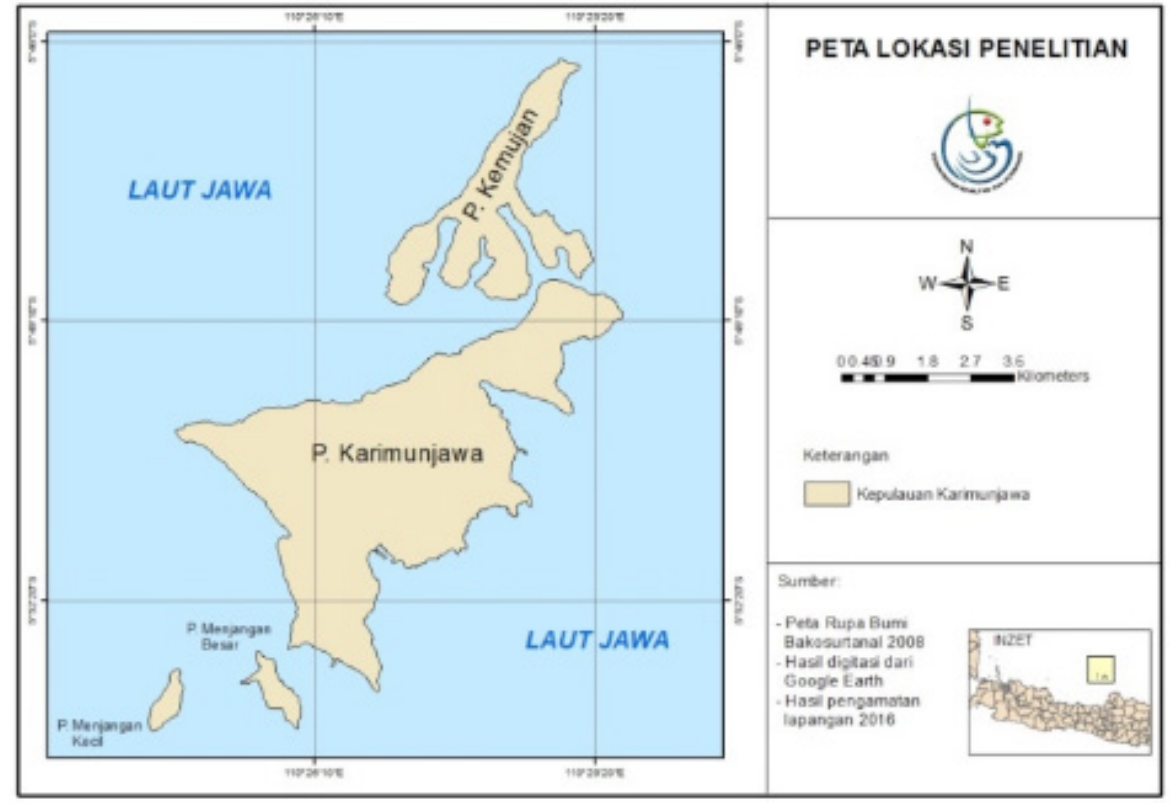

Gambar 1. Lokasi penelitian Pulau Kemujan, Pulau Karimunjawa, Pulau Menjangan Besar dan Pulau Menjangan Kecil di wilayah Kepulauan Karimunjawa, Kabupaten Jepara, Provinsi Jawa Tengah.

Figure 1. Research locations at Kemujan Island, Karimunjawa Island, Menjangan Besar Island and Menjangan Kecil Island in Karimunjawa Islands, Jepara Regency, Central Java Province. 
Tabel 1. Parameter Ancaman Gelombang Ekstrim dan Abrasi

Table 1. Extreme Wave Threat and Abrasion Parameters

\begin{tabular}{|c|c|c|c|c|}
\hline Parameter & $\begin{array}{l}\text { Bobot } \\
(\%)\end{array}$ & Rendah & $\begin{array}{l}\text { Kelas Indeks } \\
\text { Sedang }\end{array}$ & Tinggi \\
\hline Tinggi gelombang & 30 & $<1 \mathrm{~m}$ & $1-2.5 \mathrm{~m}$ & $>2.5$ \\
\hline Arus (current) & 30 & $<0.2$ & $0.2-0.4$ & $>0.4$ \\
\hline Tutupan vegetasi & 15 & $>80 \%$ & $40-80 \%$ & $<40 \%$ \\
\hline Bentuk garis pantai & 15 & berteluk & berteluk - lurus & lurus \\
\hline Tipologi pantai & 10 & berbatu karang & berbatu pasir & berlumpur \\
\hline
\end{tabular}

Sumber: BNPB, 2012

peta ancaman non SNI, yaitu jenis peta ancaman yang belum dikeluarkan oleh kementerian/lembaga terkait, sehingga ancaman gelombang ekstrim dan abrasi harus ditentukan berdasarkan Pedoman Umum Pengkajian Risiko Bencana yang termuat dalam Perka BNPB No. 2 Tahun 2012 (BNPB, 2012). Parameter yang digunakan untuk peta ancaman gelombang ekstrim dan abrasi adalah tinggi gelombang, arus laut (current), tutupan vegetasi di wilayah pesisir, bentuk garis pantai dan tipologi pantai sebagaimana tertera dalam Tabel 1.

Untuk mengukur tingkat ancaman gelombang ekstrim dan abrasi diperoleh dari Peraturan Kepala Badan Nasional Penanggulangan Bencana No 2/2012, dapat dilihat pada Persamaan 1.
Ancaman Gelombang Ekstrim dan Abrasi $=(0,3$ x skor tinggi gelombang $)+(0,3 \times$ skor arus $)+(0,15 \times$ skor tutupan vegetasi $)+(0,15 \mathrm{x}$ skor bentuk garis pantai $)+$ $(0,1 \mathrm{x}$ skor tipologi pantai)

Proses untuk mendapatkan peta ancaman gelombang ekstrim dan abrasi dilakukan melalui beberapa tahap (Gambar 2). Pada tahap awal, Peta Rupa Bumi Karimunjawa tahun 2008 dengan skala 1:250.000 yang diperoleh dari Badan Informasi Geospasial (BIG) dilakukan konversi ke dalam raster grid dengan ukuran unit $100 \times 100 \mathrm{~m}$. Kemudian dilakukan buffer $100 \mathrm{~m}$ dari garis pantai, yaitu daerah sempadan pantai. Proses olahan ini adalah untuk mendapatkan peta dasar yang digunakan dalam penelitian ini. Data

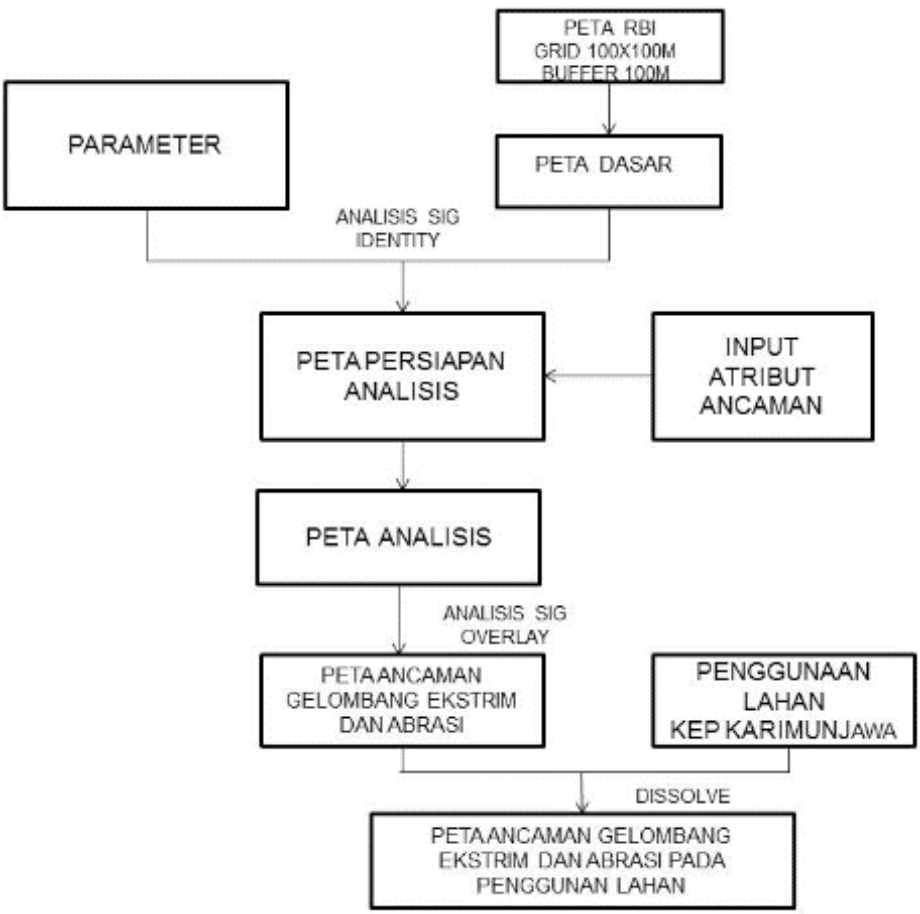

Gambar 2. Skema alur analisis Sistem Informasi Geografis (SIG) untuk mendapatkan peta ancaman gelombang ekstrim dan abrasi. (Sumber: Hasil Analisis, 2017).

Figure 2. Flowchart of Geographic Information System (GIS) analysis scheme to develop extreme and abrasion wave threat maps. (Source: Results of Analysis, 2017). 
tinggi gelombang dan pola arus permukaan diperoleh dari dataset Global Ocean Physics Analysis and Forecast yang berasal dari situs Copernicus Marine Environment Monitoring Service (CMEMS) dengan resolusi $1 / 12^{\circ}$ atau $9,25 \times 9,25 \mathrm{~km}$ (CMEMS, 2017). Basis data yang digunakan dalam model physics analysis pada CMEMS menggunakan Model NEMO (Nucleus for European Modelling of the Ocean) versi 3.1 dan memiliki ketersediaan data secara vertikal dengan 50 lapisan kedalaman. Pada analisis data arus permukaan laut menggunakan komponen utara-selatan (meridional) dan timur barat (zonal). Pengolahan data gelombang menggunakan data yang berasal dari situs European Centre for Medium-Range Weather Forecasts (ECMWF, 2017) dengan resolusi 0.125 atau $13,88 \times 13,88 \mathrm{~km}$. Parameter yang digunakan dalam analisis data gelombang adalah periode gelombang, tinggi gelombang, arah gelombang. Pada kedua data awal yang memiliki rata-rata harian kemudian diolah untuk mendapatkan rata-rata bulanan yang mewakili tiap-tiap musim yaitu Musim Barat, Musim Peralihan I dan II, serta Musim Timur. Tahap berikutnya dilakukan proses gridding resolusi data menjadi $1 \times 1 \mathrm{~km}$ yang kemudian dibuat visualisasi sebaran masing-masing parameter menggunakan perangkat lunak ODV (Ocean Data View) versi 4.7. (Schlitzer, 2015). Pada penelitian ini digunakan data Musim Barat bulan Januari karena memiliki nilai gelombang dan arus pada Januari 2015.

Tahap kedua adalah pengolahan data parameter tutupan vegetasi, yang diperoleh dari data sekunder hasil digitasi yang diperoleh dari citra Landsat 5 yang diunduh dari situs https://earthexplorer.usgs. gov/ (EarthExplorer, 2017). Akusisi data 19 Juni 2011 pada lokasi Karimunjawa berada pada level 1 dengan komposit kanal 1 sampai dengan 7, kondisi citra sudah terkoreksi geometri maupun radiometri. Citra hasil unduhan dipotong sesuai dengan lokasi penelitian, selanjutnya dilakukan komposit kanal 321 sesuai dengan warna asli atau true color. Proses analisis citra menggunakan perangkat lunak ERMapper.

Penelitian ini difokuskan pada sempadan pantai sejauh $100 \mathrm{~m}$ dari garis pantai sehingga semua parameter analisis berada pada area ini. Tahap selanjutnya, dilakukan digitasi pemanfaatan lahan dari citra klasifikasi yang terdiri dari bandara, lahan terbuka dan vegetasi, kemudian dihitung persentase tutupan vegetasi didaerah sempadan pantai sehingga didapatkan peta tutupan vegetasi. Parameter berikutnya yaitu bentuk garis pantai diolah dari Peta Rupabumi Indonesia (RBI) yang diperoleh dari situs Ina-Geoportal (2018). Bentuk garis pantai dianalisis sesuai dengan Pedoman
Umum Pengkajian Risiko Bencana berdasarkan Perka BNPB 2/2012 (BNPB, 2012) yang terdiri dari berteluk, berteluk-lurus dan lurus. Data untuk parameter terakhir yaitu data tipologi pantai diperoleh dari pengamatan lapangan dengan pengambilan sampel batuan. Sampel batuan diambil di setiap lokasi yang berbeda, selanjutnya dilakukan analisis petrografi agar dapat diketahui jenis batuan dan nama batuan.

Tahap selanjutnya setelah semua parameter dianalisis, dilakukan proses memasukkan data atribut berdasarkan kondisi lapangan. Kemudian dilakukan analisis SIG dengan proses tumpang susun semua parameter sehingga didapatkan peta ancaman gelombang ekstrim dan abrasi. Proses analisis SIG dilakukan menggunakan perangkat lunak ArcGIS. Ancaman gelombang ekstrim dan abrasi dibagi dalam tiga kelas ancaman yaitu rendah, sedang dan tinggi, dan dihitung persentase ancaman gelombang ekstrim dan abrasi untuk setiap kelas. Pembagian menjadi tiga kelas ancaman gelombang ekstrim dan abrasi diperoleh dengan mengetahui interval tiap kelas. Persamaan merupakan hasil analisis, 2017, sebagai berikut:

$G E A=\frac{\mathrm{NT}-\mathrm{NR}}{3}$

di mana,

GEA = Ancaman Gelombang ekstrim dan abrasi;

NT = nilai tertinggi; dan

NR =nilai terendah.

Pada tahap akhir dari proses analisis SIG, peta ancaman gelombang ekstrim dan abrasi ditumpangsusunkan dengan peta penggunaan lahan Kepulauan Karimunjawa yang diperoleh dari situs Ina-Geoportal (2018). Setelah dilakukan analisis dissolve, kemudian dihitung persentase ancaman gelombang ekstrim dan abrasi pada penggunaan lahan di daerah sempadan pantai. Hasil perhitungan tahap akhir ini dapat memperlihatkan tingkat ancaman gelombang ekstrim dan abrasi pada setiap penggunaan lahan di lokasi studi.

\section{HASIL DAN PEMBAHASAN}

.Kepulauan Karimunjawa memiliki keanekaragaman hayati cukup tinggi karena keberadaan lima tipe ekosistem yaitu hutan hujan tropika dataran rendah, hutan pantai, hutan mangrove, padang lamun, dan terumbu karang (Dit. KHKL, 2018), sehingga sebagian besar wilayahnya telah ditetapkan sebagai kawasan taman nasional (BTNK, 2004; Suryanti, 2010). Pulau-pulau kecil sangat rentan terhadap perubahan 
sirkulasi atmosfer dan lautan (Pelling \& Uitto, 2001), sehingga meskipun kaya akan keanekaragaman hayati, Kepulauan Karimunjawa rawan akan bencana gelombang ekstrim dan abrasi yang dapat mengakibatkan kerusakan wilayah pesisir pantainya, termasuk sumberdaya alam seperti terumbu karang serta permukiman dan infrastruktur yang ada. Wilayahwilayah di pesisir yang rawan bencana perlu diketahui, agar dapat diambil langkah kebijakan dan pengelolaan yang tepat untuk wilayah tersebut. Peningkatan bencana alam berkaitan dengan perubahan iklim (van Aalst, 2006) dan kenaikan muka laut (Rodolfo \& Siringan, 2006), atau terjadinya interaksi tekanan global dengan dinamika lokal yang memberikan pengaruh terhadap peningkatan kerentanan kepada bencana alam lingkungan (Pelling \& Uitto, 2001). Fenomena perubahan iklim semakin meningkatkan ancaman bencana hidrometeorologi (BNPB, 2014 ). Pentingnya pemanfaatan sumberdaya alam bagi perekonomian pulau-pulau kecil (perikanan, pariwisata, pertanian) berarti bahwa perubahan iklim tidak hanya berdampak langsung dengan meningkatkan risiko bencana tetapi juga berdampak tidak langsung dengan mengikis basis ekonominya (Pelling \& Uitto, 2001).

Kepulauan Karimunjawa yang terdiri dari pulau-pulau kecil termasuk wilayah rawan bencana karena terpapar dari ancaman gelombang ekstrim dan abrasi, yang kerap menyebabkan terjadinya erosi marin. Untuk itu perlud iperhatikan faktor-faktor yang berperan dalam menimbulkan ancaman gelombang ekstrim dan abrasi, yaitu tinggi gelombang dan arus laut, tutupan vegetasi, bentuk garis pantai dan tipologi pantai. Penelitian ini mengacu pada Pedoman Umum Pengkajian Risiko Bencana berdasarkan Perka BNPB 2/2012 (BNPB, 2012) menggunakan aplikasi penginderaan jauh dan sistem informasi geografis (SIG) karena merupakan alat yang dapat memperbaharui deskripsi keruangan secara berkala, mengetahui sebaran wilayah yang rawan bencana dan pengelolaan dampak kebencanaan.

\section{Tinggi Gelombang dan Arus Laut}

Berdasarkan hasil pemodelan pola arus permukaan laut di Perairan Kepulauan Karimunjawa pada Januari 2015 (mewakili Musim Barat), secara umum pola pergerakan arah arus dominan menuju ke arah timur dari arah barat. Menurut Yusuf et al. (2013) perairan Karimunjawa yang termasuk wilayah Laut Jawa dipengaruhi oleh sistem angin monsoon. Dimana pada saat angin Monsun Barat atau Musim Barat ditandai dengan pola angin yang bergerak dari arah Barat Laut menuju Tenggara dan dicirikan dengan kondisi angin kencang, gelombang laut besar, serta curah hujan yang cukup tinggi (Siregar et al., 2017). Sedangkan pada saat angin Monsun Timur atau Musim Timur aliran arus bergerak dari arah Timur ke Barat dan dicirikan dengan kondisi angin serta gelombang yang cenderung tidak besar.

Pada wilayah selatan Pulau Karimunjawa memiliki nilai kecepatan arus yang cenderung lebih tinggi berkisar 0,20-0,30 m/detik, dan berangsur melemah menuju ke arah utara Pulau Karimunjawa yaitu berkisar 0,08-0,1 m/detik. Nilai rata-rata kecepatan arus pada wilayah penelitian ketika Musim Barat adalah 0,17 $\mathrm{m} /$ detik dengan nilai maksimum sebesar $0,30 \mathrm{~m} /$ detik. Berdasarkan hasil penelitian ini menunjukkan bahwa pola arus di perairan Kepulauan Karimunjawa cenderung dipengaruhi oleh pergerakan musiman massa air Laut Jawa, dimana pada Musim Barat ratarata kecepatan arus di Laut Jawa berkisar antara 0,023$0,15 \mathrm{~m} /$ detik dengan arah arus bergerak menuju ke Selatan (Simanjorang et al., 2018).

Berdasarkan hasil analisis karakteristik tinggi gelombang pada Januari 2015 (Musim Barat) menunjukkan secara umum di bagian utara perairan Pulau Karimunjawa memiliki nilai yang lebih besar $(0,95-0,96 \mathrm{~m})$ dibandingkan pada bagian selatan $(0,92$ m). Seperti yang telah dijelaskan sebelumnya bahwa kondisi tinggi gelombang di perairan Kepulauan Karimunjawa dipengaruhi pula oleh sistem angin monsoon dan karakteristik gelombang di Laut Jawa. Pada Musim Barat berdasarkan hasil simulasi menggunakan model Simulating Wave Near-shore (SWAN) menunjukkan kisaran nilai tinggi gelombang antara 0,08 - 2,44 m (Muliati et al., 2018), sedangkan berdasarkan hasil rerata data 9 tahunan menunjukkan rata-rata tinggi gelombang berkisar antara 0,5-2,5 m (Wicaksana et al., 2015). Selanjutnya semakin menuju ke pesisir Pulau Jawa tinggi gelombang perlahan mengalami penurunan. Hal ini dapat dilihat pada wilayah perairan Pulau Menjangan Besar dan Pulau Menjangan Kecil memiliki tinggi gelombang berkisar $0,93 \mathrm{~m}$. Penurunan nilai tinggi gelombang pada daerah pesisir dapat diakibatkan oleh adanya peran ekologis terumbu karang yang merambatkan dan melemahkan gelombang tersebut. Selain itu, penurunan nilai tinggi gelombang di sekitar perairan Laut Jawa dipengaruhi pula oleh kondisi batimetri yang mendangkal (Hidayat et al., 2013; Wicaksana et al., 2015).

Secara umum nilai tinggi gelombang dan arus permukaan laut perairan Kepulauan Karimunjawa pada Musim Barat masih berada di kelas rendah, dengan nilai tinggi gelombang dibawah $1 \mathrm{~m}$ (Gambar

Ancaman Gelombang Ekstrim dan Abrasi pada Penggunaan Lahan di Pesisir Kepulauan Karimunjawa (Studi Kasus: 


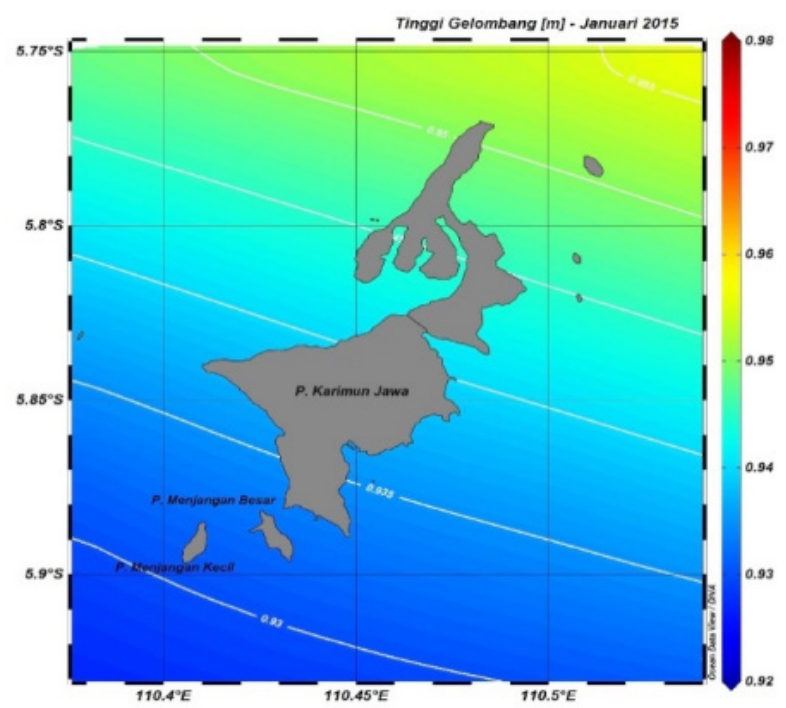

Gambar 3. Sebaran tinggi gelombang perairan Kepulauan Karimunjawa pada Januari 2015.

Figure 3. The high distribution of the waters of the Karimunjawa Islands on January 2015.

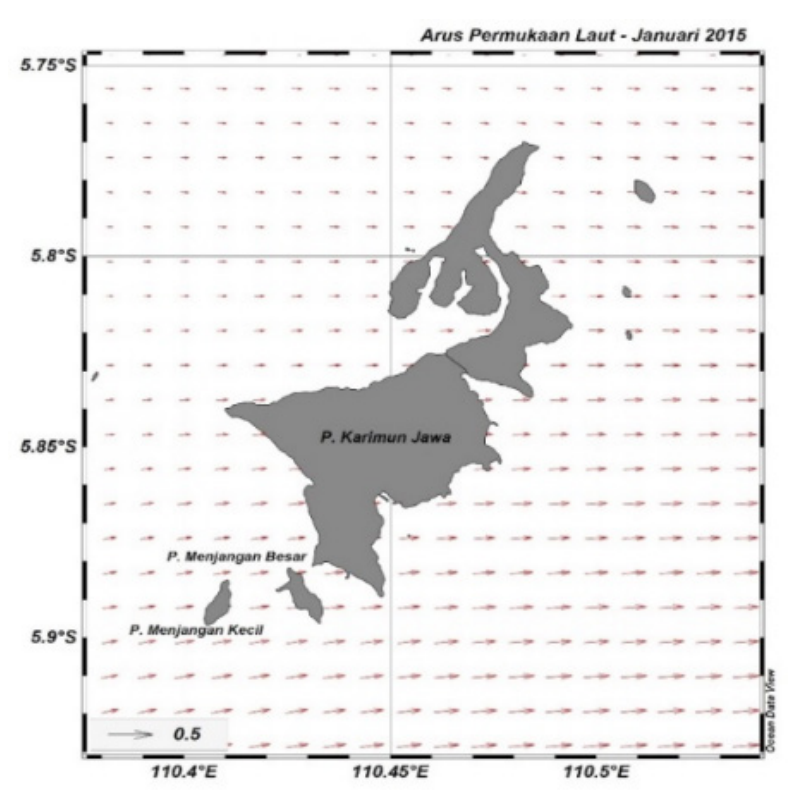

Gambar 4. Pola arus permukaan laut Kepulauan Karimunjawa pada Januari 2015.

Figure 4. The pattern of the sea surface current in Karimunjawa Islands coastal waters in January 2015.

3) dan arus dibawah $0,2 \mathrm{~m} /$ detik (Gambar 4). Peta hasil analisis tinggi gelombang dan arus laut di lokasi penelitian disajikanpada Gambar 3 dan Gambar 4.

\section{Tutupan Vegetasi}

Tutupan vegetasi di lokasi penelitian secara umum berada dikelas rendah, artinya lebih dari $80 \%$ daerah sempadan pantai memiliki tutupan vegetasi. Beberapa lokasi berada di kelas tinggi dengan tutupan vegetasi kurang dari $40 \%$, terutama di pusat permukiman dan kegiatan di bagian selatan dan timur Pulau Karimunjawa, di bagian timur dan selatan Pulau Kemujan, di barat dan timur Pulau Menjangan Besar, dan di bagian utara dan timur laut Pulau Menjangan Kecil. Lokasi lain

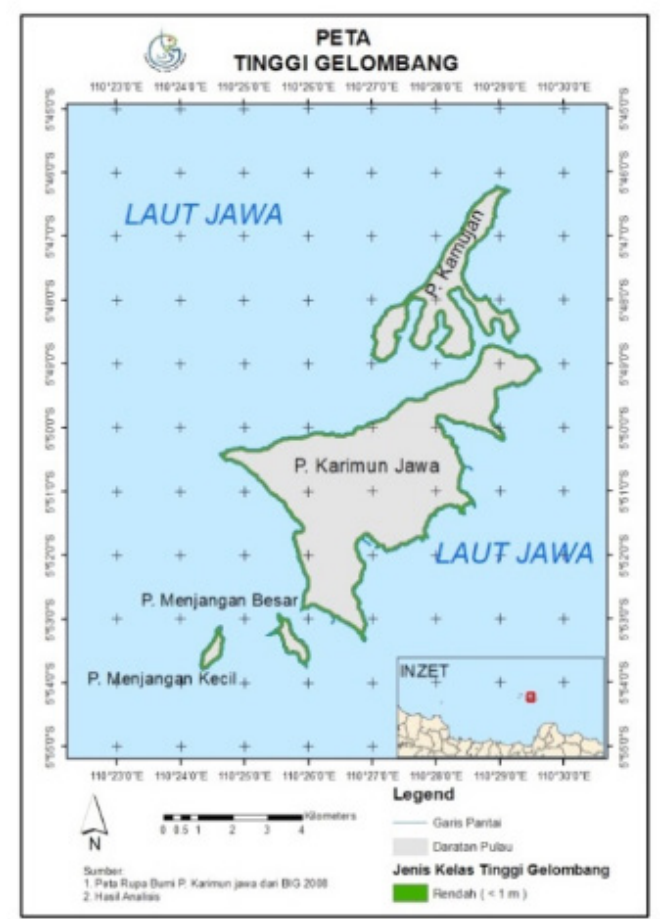

Gambar 5. Peta analisis tinggi gelombang di lokasi penelitian.

Figure 5. Wave height analysis map at the research location.

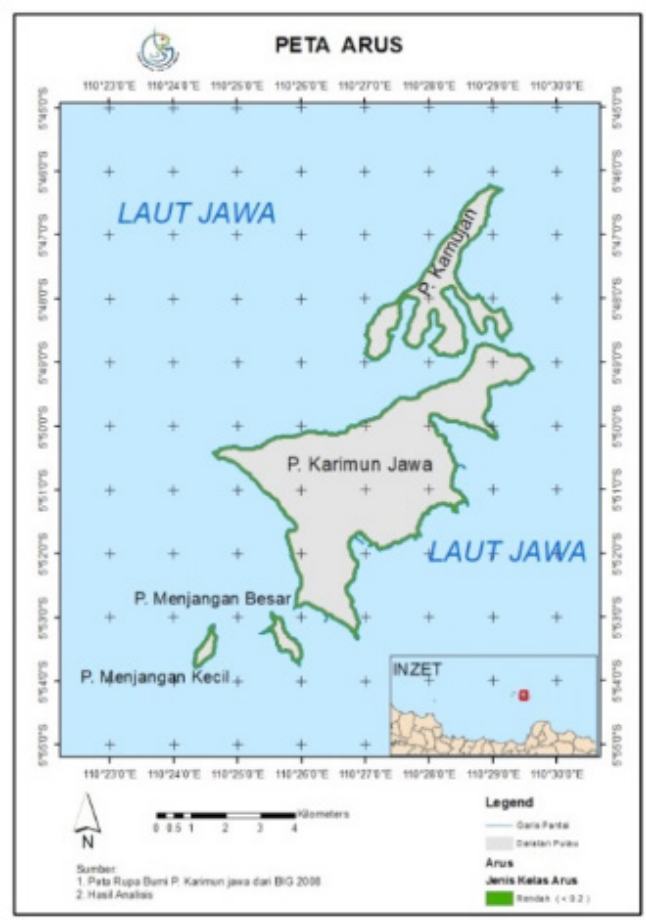

Gambar 6. Peta analisis arus di lokasi penelitian.

Figure 6. Map of flow analysis at the research location. 


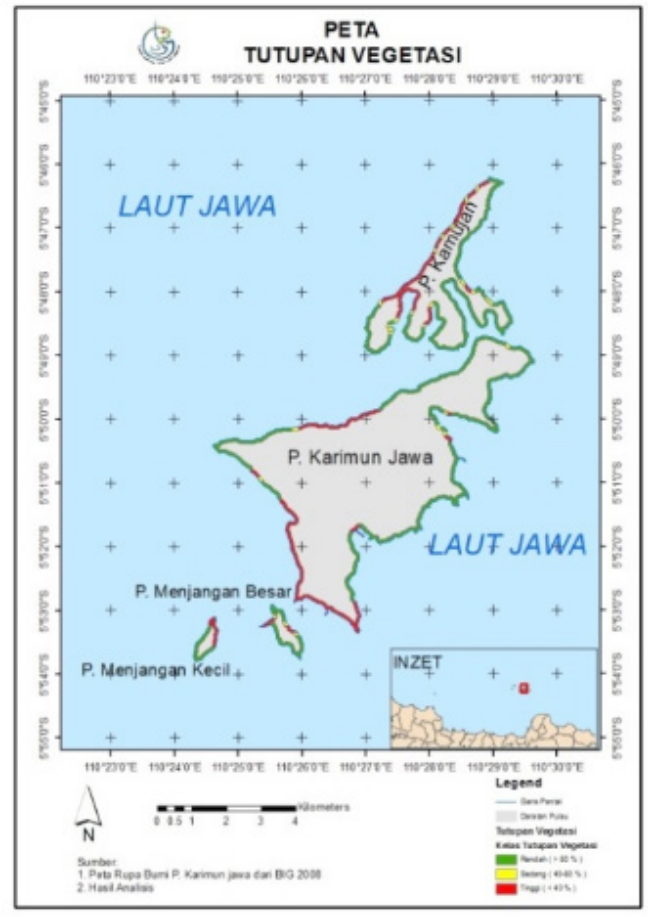

Gambar 7. Peta kelas tutupan vegetasi di lokasi penelitian. Figure 7. Map of vegetation cover class at the research location.

termasuk kelas sedang dengan tutupan vegetasi 40$80 \%$. Peta analisis tutupan vegetasi ditampilkan pada Gambar 7.

\section{Bentuk Garis Pantai}

Kepulauan Karimunjawa dibedakan menjadi tiga satuan yaitu perbukitan, perbukitan bergelombang dan dataran rendah. Perbukitan hanya terdapat di Pulau Karimunjawa terbentang luas dengan ketinggian antara 200-500 mdpl. Puncak teringgi gunung Bendera (506 mdpl). Perbukitan bergelombang terbentang di Pulau Karimunjawa, Kemujan dengan ketinggian antara 25-200 mdpl. Dataran rendah terbentang di P. Karimunjawa dengan ketingian antara 0-25 mdpl. Pulau Karimunjawa memiliki topografi lahan berupa perbukitan curam dengan ketinggian mencapai 500 mdpl (Sidarto \& Hermanto, 1993).

Mengamati kondisi geomorfologi Kepulauan Karimunjawa yang terbagi dalam tiga satuan sehingga bentuk garis pantai mengikuti morfologi Kepulauan Karimunjawa. Hasil pengamatan bentuk garis pantai tersebut secara garis besar berada di kelas sedang artinya cukup resisten terhadap ancaman gelombang. Di pusat permukiman dan kegiatan bentuk garis pantai lurus memanjang dan sebagian kecil bentuk garis pantai berteluk. Sebaran bentuk garis pantai ditampilkan pada Gambar 8 .

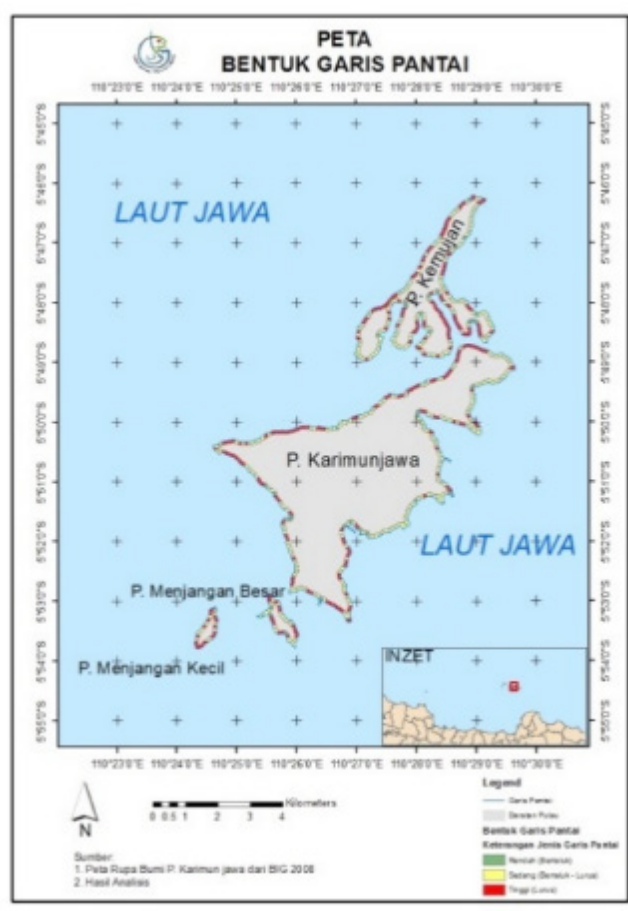

Gambar 8. Peta bentuk garis pantai di lokasi penelitian. Figure 8. Map of coastline shape at the research location.

Berdasarkan Peta Geologi Lembar Pulau Karimunjawa (Sidarto \& Hermanto, 1993) bahwa batuan yang tersingkap di wilayah Kepulauan Karimunjawa terdiri batupasir kuarsa, batu pasir mikaan, konglomerat kuarsa, batu lanau kuarsa atau serpih kuarsa dan urat kuarsa. Jenis batuan ini termasuk dalam Formasi Karimunjawa (pTk), yang berumur pra tersier. Pesisir sekitar P. Karimunjawa terdapat satuan batuan muda berupa alluvium terdiri dari endapan pantai dan endapan rawa. Jenis batuan serupa terdapat di P. Menjangan Besar dan P. Menjangan Kecil. P. Kamujan satuan batuan di pesisir adalah alluvium dan Formasi Karimunjawa (pTk) serta Formasi Parang (Tmpv). Komposisi Formasi Parang terdiri dari breksi, gunungapi, tuf dan lava.

Sebaran satuan batuan di pesisir P. Karimunjawa, P. Menjangan Besar, P. Menjanga Kecil dan P. Kamujuan didominasi oleh satuan batuan alluvium, satuan formasi Karimunjawa dan Formasi Parang, yang tersebar di wilayah perkotaan, pedesaan dan tempat wisata. Hasil pengolahan jenis batu pasir dan pasir konglomerat mendominasi pesisir pantai sehingga dapat dikategorikan berada dikelas sedang. Kondisi tipologi pantai di lokasi penelitian disajikan pada Gambar 9.

Setelah diketahui kondisi sebaran setiap parameter ancaman gelombang ekstrim dan abrasi, maka dapat

Ancaman Gelombang Ekstrim dan Abrasi pada Penggunaan Lahan di Pesisir Kepulauan Karimunjawa (Studi Kasus:

Pulau Kemujan, Pulau Karimunjawa, Pulau Menjangan Besar dan Pulau Menjangan Kecil) - Dini Purbani, Hadiwijaya 


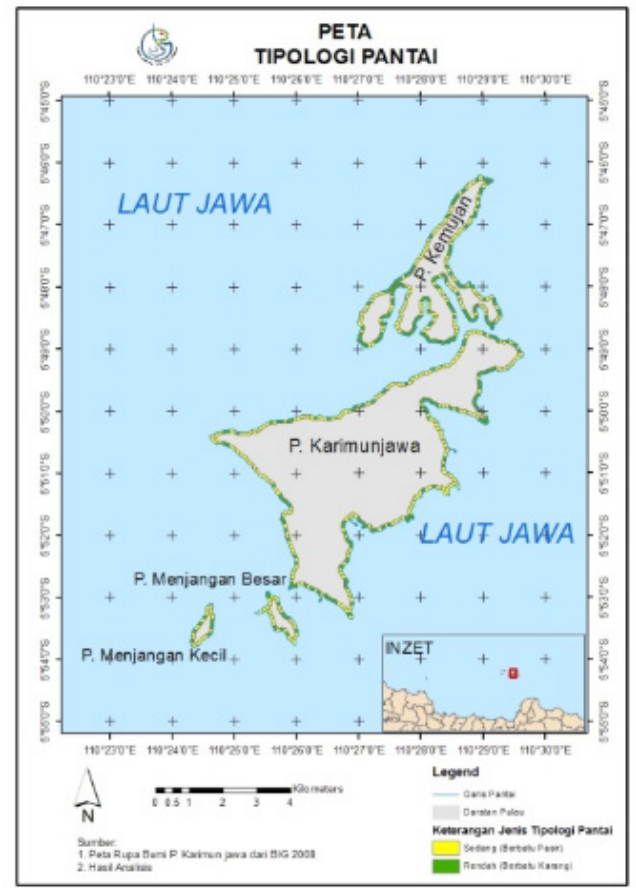

Gambar 9. Peta tipologi pantai di lokasi penelitian.

Figure 9. Beach typology map at the research location.

diketahui tingkat ancaman gelombang ekstrim dan abrasi di Kepulauan Karimunjawa, yang dibagi dalam tiga kelas yaitu rendah, sedang dan tinggi (Tabel 2). Hasil perhitungan dengan persamaan 1 menghasilkan nilai tertinggi 1,7 dan nilai terendah 0,2 . Pembagian kelas rendah, sedang dan tinggi menggunakan persamaan 2 dengan membagi nilai tertinggi dan terendah dibagi menjadi 3 kelas sehingga interval antar kelas adalah 0,5. Luas sebaran ancaman gelombang ekstrim dan abrasi dan Peta Ancaman Gelombang Ekstrim dan Abrasi di lokasi penelitian disajikan dalam Tabel 3.

Berdasarkan hasil analisis sebaran ancaman gelombang ekstrim dan abrasi dengan menampilkan semua parameter, maka wilayah sempadan pantai di Pulau Kemujan, Pulau Karimunjawa, Pulau Menjangan Besar dan Pulau Menjangan Kecil memiliki tingkat ancaman gelombang ekstrim dan abrasi yang tinggi dengan luas 565,15 ha, atau $80,67 \%$ dari total luas sempadan pantai (Gambar 10). Sebaran ancaman gelombang ekstrim dan abrasi dengan kelas sedang berada di Pulau Kemujan, Pulau Karimunjawa, dan sebagian kecil di Pulau Menjangan Besar dan Pulau Menjangan Kecil, dengan luas 135,42 ha atau $19,33 \%$ dari total luas sempadan pantai. Sebaran ancaman gelombang ekstrim dan abrasi dengan kelas rendah hanya terdapat di Pulau Kemujan dengan luas 0,031 ha atau $0,01 \%$ dari total luas sempadan pantai. Dengan diketahui luas sebaran ancaman gelombang ekstrim dan abrasi di wilayah sempadan pantai yang sebagian besar berada di kelas tinggi, akan sangat mempengaruhi penggunaan lahannya. Adapun Penggunaan lahan Karimunjawa menurut Yusuf (2007) terdiri dari: hutan tropis, kebun campuran, kebun kelapa, mangrove, permukiman, sawah, tambak dan tegalan/ladang. Hasil dari analisis penggunaan lahan di Pulau Kemujan, Pulau Karimunjawa, Pulau Menjangan Besar dan Pulau Menjangan Kecil yang berada di pesisir sangat bervariasi, dilakukan penampalan antara Peta Penggunaan Lahan dengan Peta Ancaman Gelombang Ekstrim dan Abrasi agar dapat diketahui

Tabel 2. Parameter Ancaman Gelombang Ekstrim dan Abrasi

Table 2. Distribution of interval class with extreme wave and abrasion threats

\begin{tabular}{llll}
\hline No & Interval & $\begin{array}{l}\text { Pembagian Kelas Ancaman } \\
\text { Gelombang Ekstrim dan Abrasi (GEA) }\end{array}$ & $\begin{array}{l}\text { Tingkat Ancaman Gelombang } \\
\text { Ekstrim dan Abrasi }\end{array}$ \\
\hline 1. & $0,2-0,5$ & GEA $<0,5$ & Rendah \\
2. & $0,5-1,2$ & $0,5<$ GEA $<1,2$ & Sedang \\
3. & $1,2-1,7$ & GEA $>1,2$ & Tinggi \\
\hline
\end{tabular}

Sumber: Hasil Analisis, 2017

Tabel 3. . Luas sebaran ancaman gelombang ekstrim dan abrasi di Pulau Kemujan, Pulau Karimunjawa, Pulau Menjangan Besar dan Pulau Menjangan Kecil.

Table 3 Distribution area of extreme and abrasion threat in Kemujan Island, Karimunjawa Island, Menjangan Besar Island and Menjangan Kecil Island.

\begin{tabular}{llll}
\hline No & Kelas & Luas $\left(\mathbf{k m}^{2}\right)$ & Persentase (\%) \\
\hline 1. & Rendah & 0,000031 & 0,0004 \\
2. & Sedang & 1,3541 & 19,3286 \\
3. & Tinggi & 5,6515 & 80,6709 \\
\hline
\end{tabular}


jenis penggunaan lahan apa saja yang berada di kelas yang tinggi, sedang atau rendah. Hasil tampalan antara kedua peta menghasilkan Peta Penggunaan Lahan di area ancaman gelombang abrasi dan ekstrim seperti pada Gambar 11.

Sebaran ancaman gelombang ekstrim dan abrasi terdapat disetiap penggunaan lahan yang berada di sempadan pantai di lokasi studi. Dari uraian diatas luas ancaman gelombang ekstrim dan abrasi yang berada di kelas tinggi cukup luas, sekitar 565 ha atau 80,76\% dari total luasan sempadan pantai. Adapun jenis-jenis penggunaan lahan di lokasi studi disajikan dalam Tabel 4.

Dari hasil analisis menunjukkan penggunaan lahan yang terancam gelombang ekstrim dan abrasi dengan luas antara 1 hingga $4 \mathrm{~km}^{2}$ adalah perkebunan/ kebun dan hutan mangrove. Dengan demikian dapat dikatakan bahwa di Kepulauan Karimunjawa area permukiman cukup aman dari ancaman gelombang ekstrim dan abrasi atau memiliki tingkat ancaman rendah, karena luas wilayah yang terancam mencakup 20,33 ha. Hal ini disebabkan karena area permukiman di lokasi studi berada lebih dari $100 \mathrm{~m}$ dari garis pantai, yang berarti tidak melampaui batas sempadan pantai, sebagaimana diatur dalam UU No. 27 Tahun 2007 jo. UU No. 1 Tahun 2014 tentang Pengelolaan Wilayah

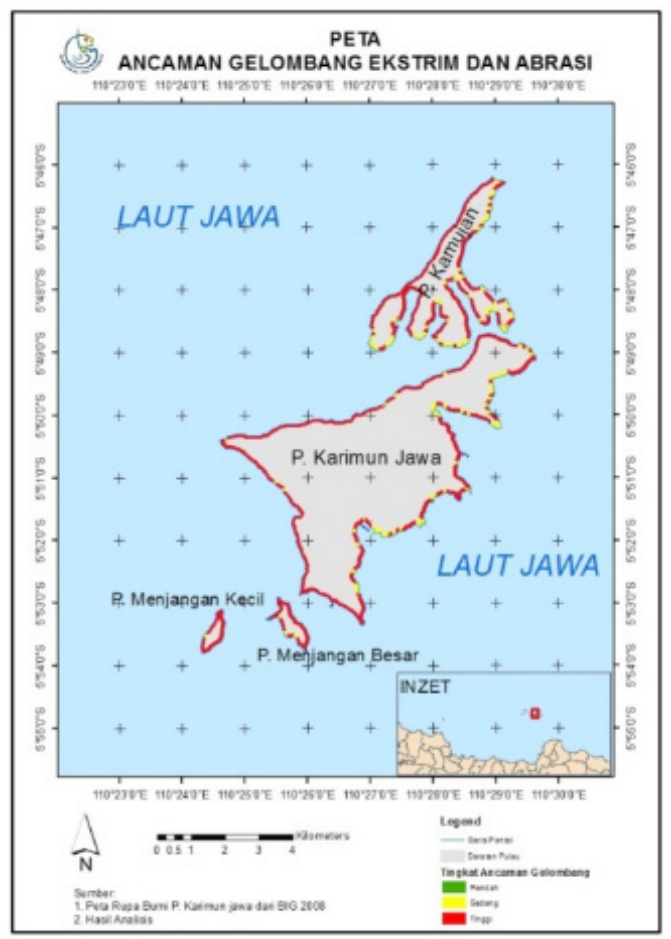

Gambar 10. Peta ancaman gelombang ekstrim dan abrasi. Figure 9. Extreme wave and abrasion threat maps.

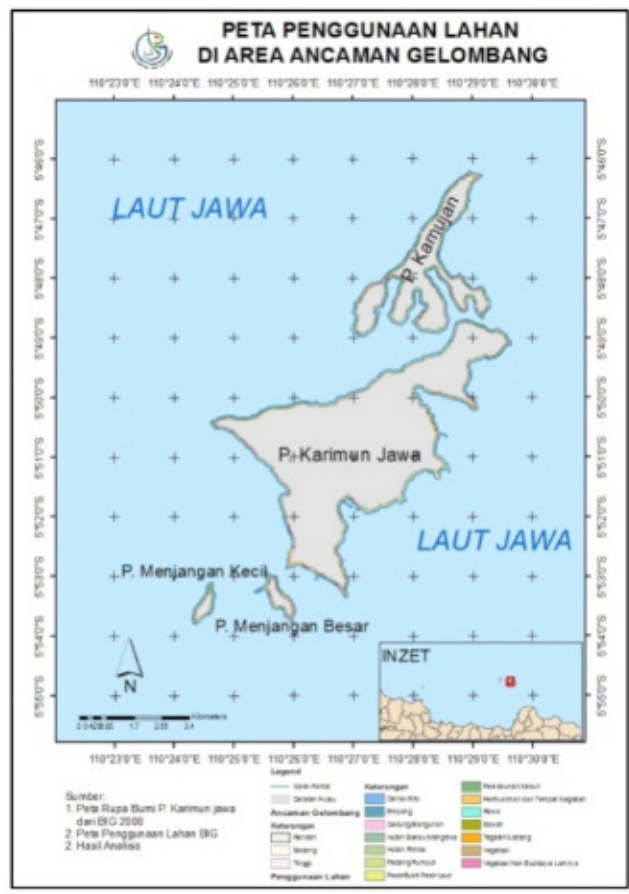

Gambar 11. Peta penggunaan lahan di area ancaman gelombang ekstrim dan abrasi di Pulau Kemujan, Pulau

Karimunjawa, Pulau Menjangan Besar dan Pulau Menjangan Kecil.

Figure 11. Map of land use in the area of extreme and abrasion threat in Kemujan Island, Karimunjawa Island, Menjangan Besar Island and Menjangan Kecil Island.

Pesisir dan Pulau-Pulau Kecil.

\section{KESIMPULAN DAN SARAN}

Hasil analisis Sistem Informasi Geografis (SIG) untuk mengetahui tingkat ancaman gelombang ekstrim dan abrasi di daerah sempadan pantai di Pulau Kemujan, Pulau Karimunjawa, Pulau Menjangan Besar dan Pulau Menjangan Kecil di Kepulauan Karimunjawa, Kabupaten Jepara, Provinsi Jawa Tengah didapatkan tiga kelas acaman yaitu: rendah $(0,01 \%)$, sedang $(19,33 \%)$ dan tinggi $(80,67 \%)$. Penggunaan lahan yang sangat terancam yaitu perkebunan/kebun (48,33\%), terancam sedang yaitu hutan mangrove $(23,28 \%)$ dan terancam rendah yaitu vegetasi $(13,05 \%)$. Dalam penelitian ini hanya dilakukan analisis untuk mengetahui tingkat ancaman bencana di lokasi penelitian, khususnya ancaman gelombang ekstrim dan abrasi. Untuk itu dalam penelitian selanjutnya, perlu dilakukan analisis tingkat kerentanan, tingkat kapasitas dan tingkat risiko bencana untuk melengkapi proses pengkajian risiko bencana di lokasi studi.

Ancaman Gelombang Ekstrim dan Abrasi pada Penggunaan Lahan di Pesisir Kepulauan Karimunjawa (Studi Kasus:

Pulau Kemujan, Pulau Karimunjawa, Pulau Menjangan Besar dan Pulau Menjangan Kecil) - Dini Purbani, Hadiwijaya 
Tabel 4. Luas dan Persentasi Penggunaan Lahan padaAncaman Gelombang Ekstrim dan Abrasi Kelas Tinggi. Table 4. Area and Percentage of Land Use and Extreme Wave Threats and High Class Abrasion.

\begin{tabular}{llll}
\hline No & Penggunaan Lahan & Luas $\left(\mathbf{k m}^{2}\right)$ & Persentase $(\%)$ \\
\hline 1. & Perkebunan/Kebun & 3,5131 & 48,3305 \\
2. & Hutan Mangrove & 1,6921 & 23,2782 \\
3. & Vegetasi & 0,9488 & 13,0522 \\
4. & Hutan Rimba & 0,3727 & 5,1279 \\
5. & Padang Rumput & 0,2570 & 3,5353 \\
6. & Permukiman dan & 0,2033 & 2,7968 \\
& Tempat Kegiatan & & \\
7. & Tegalan/Ladang & 0,0889 & 1,2228 \\
8. & Rawa & 0,0863 & 1,1869 \\
9. & Empang & 0,0645 & 0,8868 \\
10 & Danau/Situ & 0,0146 & 0,2005 \\
11. & Pasir/Bukit Pasir Laut & 0,0123 & 0,1689 \\
12. & Sawah & 0,0093 & 0,1280 \\
13. & Vegetasi Non & 0,0056 & 0,0775 \\
& Budidaya Lainnya & & \\
14. & Gedung/Bangunan & 0,0005 & 0,0074 \\
\hline
\end{tabular}

\section{UCAPAN TERIMA KASIH}

Penulis mengucapkan terima kasih kepada Kepala Pusat Penelitian Kelautan dan Tim Kerja Blue Carbon, yang telah memberikan fasilitas dalam penelitian ini serta rekan kerja yang turut berpartisipasi dalam penyelesaian tulisan ini. Survei pengukuran di lokasi penelitian dibiayai oleh APBN DIPA TA 2016 Pusat Riset Kelautan BRSDM KP.

\section{DAFTAR PUSTAKA}

Amri, M. R., Yulianti, G., Yunus, R., Wiguna, S., Adi, A.W., Ichwana, A. N., Randongkir, R. E. \& Septian. R. T. (2016). Risiko Bencana Indonesia. Direktorat Pengurangan Risiko Bencana. Badan Nasional Penanggulangan Bencana. Jakarta.

van Aalst, M. K. (2006). The impacts of climate change on the risk of natural disasters. Disasters, 30(1), 5-18.

Bengen, D. G., Retraubun, A. S., \& Saad, S. (2012). Menguak Realitas dan Urgensi Pengelolaan Berbasis Ekososio Sistem Pulau-Pulau Kecil.

BNPB. (2012). Peraturan Kepala Badan Nasional Penanggulangan Bencana tentang Pedoman Umum Pengkajian Risiko Bencana.

BNPB. (2014). Rencana Nasional Penanggulangan Bencana 2015-2019.

BPS Kab Jepara. (2017). Kecamatan Karimunjawa Dalam Angka 2017. viii $+104 \mathrm{hlm}$.

BTN Karimunjawa. (2004). Penataan Zonasi Taman Nasional Karimunjawa, Kabupaten Jepara, Provinsi Jawa Tengah (2), p. 63. Available at: http://www.tnkarimunjawa.com.

CEMS. (2017). Global Ocean 1/12 ${ }^{\circ}$ Physics Analysis and
Forecast Updated Daily. Cited in http://forum.marine. copernicus.eu/discussion/216/update-time-globalocean-112-physics-analysis-and-forecast-updateddaily/p1. [20 Agustus 2017].

Dahdouh-guebas, F. (2002). The Use of Remote Sensing and GIS in The Sustainable Management of Tropical Coastal Ecosystems. Environment, Development and Sustainability, 4(9), 93-112. doi: 10.1023/A:1020887204285.

[Dit. KKHL] Direktorat Konservasi dan Keanekaragaman Hayati Laut. (2018). Data Kawasan Konservasi Taman Nasional Laut Karimunjawa. Direktorat Konservasi dan Keanekaragaman Hayati Laut. Direktorat Jenderal Pengelolaan Ruang Laut. Kementerian Kelautan dan Perikanan. Cited in http:// kkji.kp3k.kkp.go.id/index.php/basisdata-kawasankonservasi/details/1/13. [23 Februari 2018].

EarthExplorer. (2017). U.S. Department of the Interior. U.S. Geological Survey. Cited in https://earthexplorer. usgs.gov/. [5 September 2017].

[ECMWF] European Centre for Medium-Range Weather Forecasts. (2017). ERA Interim, Daily. Cited in http:// apps.ecmwf.int/datasets/data/interim-full-daily/ levtype $=$ sfc/. [20 Agustus 2017].

Fachrurrozi, M., Widada, S., \& Helmi, M. (2013). Studi Pemetaan Batimetri Untuk Keselamatan Pelayaran Di. Jurnal Oseanografi, 2(3), 310-317.

Garcin, M., Desprats J. F., Fontaine M., Pedreros R., Attanayake N., Fernando S., Siriwardana C. H. E. R., De Silva U., \& Poisson B. (2008). Integrated approach for coastal hazards and risks in Sri Lanka. Nat. Hazards Earth Syst. Sci. (8), 577-586.

JURNAL KELAUTAN NASIONAL, Vol. 14, No 1, April 2019, Hal. 33-45 
Hadi, S.I., Arsadi, E.M., Hartanto, P \& Marganingrum, D. (2006). Kualitas Air Tanah Bebas Kota Karimunjawa, Pulau Karimunjawa. Jurnal Riset Geologi dan Pertambangan, 16(2), 27-50.

Hehanussa, P.E. (1993). Morphogenetic Classification of Small Island as basis for Resources Planning in Indonesia. Seminar on Small Island Hydrology, UNESCO-ROSTSEA, Batam Island, 13p.

Hidayat, J. J., Muh. Y., \& Elis I. (2013). Dinamika Penjalaran Gelombang Menggunakan Model CMS-Wave di Pulau Parang Kepulauan Karimunjawa, Jurnal Oseanografi, 2(27), 255-264.

Ina-Geoportal. (2018). Geospasial untuk Negeri. Cited in http://tanahair.indonesia.go.id/portal-web. [19 Januari 2018].

Muliati, Y., Tawekal, R. L., Wurjanto, A., Kelvin, J., \& Pranowo, W. S. (2018). Application of SWAN model for hindcasting wave height in Jepara Coastal Waters, North Java, Indonesia. International Journal of GEOMATE, 15(48), 114-120.

Musa, M., Handoyono, G., \& Setyono, H. (2013). Peramalan Pasang di Perairan Pulau Karimunjawa, Kabupaten Jepara, menggunakan Program "Worldtides". Jurnal Oseanografi, 3(1), 1-7.

Pelling, M., \& Uitto, J. I. (2001). Small island developing states: natural disaster vulnerability and global change. Global Environmental Change Part B: Environmental Hazards, 3(2), 49-62.

Peraturan Daerah Propinsi Jawa Tengah Nomor 22 Tahun (2003) Tentang Pengelolaan Kawasan Lindungdi Propinsi Jawa Tengah.

Peraturan Kepala Badan Meteorologi, Klimatologi, dan Geofisika Nomor : KEP. 009 Tahun 2010 Tentang Prosedur Standar Operasional Pelaksanaan Peringatan Dini, Pelaporan, dan Diseminasi Informasi Cuaca Ekstrim.

Peraturan Presiden Republik Indonesia Nomor 51 Tahun 2016 Tentang Batas Sempadan Pantai.

Rodolfo, K. S., \& Siringan, F. P. (2006). Global sea-level rise is recognised, but flooding from anthropogenic land subsidence is ignored around northern Manila Bay, Philippines'. Disasters, 30(1), 118-139.

Ruswandi, Asep S., Syafri M., Etty R., \& Priyadi K. (2008). Identifikasi Potensi Bencana Alam dan Upaya Mitigasi yang Paling Sesuai Diterapkan di Pesisir Indramayu dan Ciamis, Jurnal Riset Geologi dan Pertambangan, 2(2), 1-19.

Schlitzer, R. (2015). Ocean Data View. http://odv.awibremerhaven.de

Sidarto, S. S., \& B. Hermanto (1993). Peta Geologi Lembar Karimunjawa Jawa, Pusat Penelitian dan Pengembangan Geologi, Indonesia.

Simanjorang, J. E., Pranowo, W. S., Sari, L. P., Purba, N. P., \& Syamsuddin, M. L. (2018). Building up the database of the Level-2 Java Sea Ecoregion based on physical oceanographic parameters. IOP Conference Series: Earth and Environmental Science, 176(1).

Siregar, S. N., Sari, L. P., Purba, N. P., Pranowo, W. S., \&
Syamsuddin, M. L. (2017). Pertukaran massa air di Laut Jawa terhadap periodisitas monsun dan Arlindo pada tahun 2015. Depik, 6(1), 44-59.

Suryanti (2010). Degradasi Pantai Berbasis Ekosistem Di Pulau Karimunjawa Kabupaten Jepara.

Theilen-Willige, B., Paraskevas S., Illias N. T., \& Ionnna P. (2012). Remote Sensing and Geographic Information Systems (GIS) Contribution to the Inventory of Infrastructure Susceptible to Earthquake and Flooding Hazards in North-Eastern Greece. Geosciences, 2(4), 203-220.

Undang-Undang Republik Indonesia Nomor 26 Tahun 2007 Tentang Penataan Ruang.

Undang-Undang Republik Indonesia Nomor 27 Tahun 2007 Tentang Pengelolaan Wilayah Pesisir dan PulauPulau Kecil.

Undang-Undang Republik Indonesia Nomor 1 Tahun 2014 Tentang Perubahan Atas Undang-Undang Nomor 27 Tahun 2007 Tentang Pengelolaan Wilayah Pesisir dan Pulau-Pulau Kecil.

Wicaksana, S., Sofian, I., Pranowo, W., Kuswardani, A. R. T. D., Saroso \& Sukoco, N. B. (2015). Karakteristik Gelombang Signifikan di Selat Karimata dan Laut Jawa berdasarkan Rerata Angin 9 Tahunan (20052013), Omni-Akuatika, 11(2), 33-40.

Yusuf, M. (2013). Kondisi terumbu karang dan potensi ikan di perairan Taman Nasional Karimunjawa, Kabupaten Jepara. Buletin Oseanografi Marina, 2, 54-60.

Yusuf, M. (2007). Kebijakan Pengelolaan Sumberdaya Pesisir dan Laut Kawasan Nasional Karimunjawa Secara Berkelanjutan. Disertasi Institut Pertanian Bogor. 
